\title{
Design of Quadrilateral Learning with RME Approach for Junior High School Students
}

\author{
Chairunnisa Inayatusufi ${ }^{1,}$ a) , Tian Abdul Aziz ${ }^{2, \text { b) }}$ \\ ${ }^{1,2}$ State University of Jakarta \\ Email: a)chairunnisainayatusu_1309820008@mhs.unj.ac.id,b)tian_aziz@unj.ac.id
}

\begin{abstract}
The purpose of this study is to provide alternative learning options, with a realistic mathematics education learning design or RME on quadrilaterl material for Junior High School students. This writing uses instructional design to develop a learning model. Learning development is done by analyzing needs and learners. Performance objectives and learning outcomes are discussed in detail and adapted to instructional objectives. The results of this study indicate that a quadrilateral learning design by applying the RME approach is recommended for educators in conducting quadrilateral learning. This happens because learning is based on real life or situations that can be imagined by students which are in accordance with RME characteristics, so that they can help students understand quadrilaterals.
\end{abstract}

Key words: RME, learning design, quadrilateral, junior high school students

\section{INTRODUCTION}

The quadrilateral is one of the basic mathematical concepts that is very important to learn at the junior high school level (Rahaju, 2018; Nisiyatussani et al, 2018). In general, quadrilaterals are included in the type of flat wake consisting of parallelograms, rectangles, squares, rhombuses, kites and trapezoids (Inharjanto, 2018). This material consists of abstract geometric concepts and definitions needed in solving problems related to the use of geometry in everyday life (Gunhan, 2014). In addition, quadrilaterals are basic prerequisites for studying more abstract material at the junior high school level such as the Pythagorean theorem and spatial figures (Martadinata, 2020; Sumiati \& Agustini, 2020). Therefore, students need to master and understand the concepts of quadrilaterals well.

Learning quadrilateral material for junior high school students is very important, but in reality it is not fully optimal. Based on the results of research conducted by Aisyah et al (2017), it was revealed that the problem-solving abilities of junior high school students were low, especially in terms of quadrilaterals. The following are some types of errors made by students in solving two-dimensional square image problems, namely errors in translating problems including errors in determining the length of the sides of a quadrilateral, conceptual errors in determining the circumference formula and calculation errors (Hadiyanti, 2016; Adhitya, 2018).

Based on these problems, a rectangular learning process is needed that includes contextual activities, in order to build student constructivity, develop models, and utilize existing understanding to make it easier to understand abstract material, so that it can become real (Mahendra et al, 2017). One approach to learning mathematics that is contextually oriented or realistic mathematization is the RME Approach (Martadinata, 2020). RME is an approach that applies reality as a starting point in the teaching and learning process and aims to support students in building and rediscovering their knowledge and making learning meaningful for students (Gravemeijer, 2010; Panhuizen, 2014). In addition, based on the results of previous studies, It is known that RME can improve students' ability in quadrilateral material. 
Meaningful learning for students is carried out with contextual learning or involving realistic problems that are known to students (Panhuizen, 2014). Based on the results of several studies, it is known that the design of mathematics learning can be developed with the RME approach on several topics, namely building space, number patterns and comparisons for junior high school students and can improve students' cognitive abilities (Jamaan, 2018; Rudiono, et al., 2015; Fauzan \& Diana 2018). Judging from the things that have been described previously regarding some rectangular problems that occur in junior high school students and the effectiveness of the RME approach in developing learning designs based on previous studies, to answer the problem, it is necessary to study how to teach quadrilaterals by applying RME, to be interesting and easy for students to understand.

Based on the background that has been mentioned, the novelty in this research is to develop a learning design with an RME approach for junior high school students on the subject of quadrilaterals. The term learning design is an activity to determine what learning approach is best implemented in order to cause changes in knowledge and skills in students in order to achieve learning objectives or in the desired direction (Hamzah and Muhlisrarini, 2014).

The learning materials selected in this article are limited to rectangular, rectangular and square subjects. This study focuses on designing the learning of rectangular and square subjects by applying RME at the junior high school level. The purpose of writing this article is to find out how to design mathematics learning on the subject of rectangles and squares at the junior high school level by applying RME. The following is a description of the meaning of RME and the characteristics of RME.

\section{Realistic Mathematics Education (RME)}

Realistic mathematics education is based on Freudenthal's idea of mathematics as a human activity (Gravemeijer, 1994). This shows that Freudenthal does not place mathematics as a finished product or a closed system, but as a form of activity or process (Wijaya, 2012; Sitorus, 2016). Mathematics must be related to reality and experience, and relevant to the context of everyday life (real-world), so that students can find their knowledge (Sumirattana et al, 2017). The context mentioned is a realistic concept that is a component of the thinking scheme. These components then connect various mathematical contexts and concepts (Sitorus, 2016).

Although the concept of realistic in the real world sense is important in RME, realistic has a broader connotation. According to Van den Heuvel-Panhuizen (2020), the use of the word realistic does not always indicate a connection with the real world (real-world) but rather refers to the focus of Realistic Mathematical Education in placing emphasis on using situations that can be imagined by students. A problem can be called realistic if the problem can be imagined (imaginable) or real (real) in the minds of students (Astuti, 2019). So it can be said that the realistic in RME is not required to be real, but can only be imagined. So if students are offered a problem situation that they can imagine in their minds, then it is included in the realistic concept.

\section{RME Characteristics}

Laurens et al., (2017) stated that the main characteristics of RME include the application of a meaningful context, the development of models that allow the transformation from contextual to formal mathematics. In line with that, according to Heuvel-Panhuizen and Drijvers (2014), RME reflects the view of mathematics as a subject matter, namely how students learn mathematics and how mathematics should be taught. This view is broken down into the characteristics of RME. The five characteristics of RME (Treffer, 1987; Grafimeijer 1994) are: (a) phenomenological exploration, (b) use models, (c) student contribution, (d) interactivity, (e) intertwinment. The five characteristics can be described as follows:

a. Use of context

Realistic contexts or problems are used as a starting point for learning and do not have to be real world problems but can be in the form of other situations, as long as they are meaningful to students (Julie et al, 2014; Afriansyah, 2016). Through the use of context, students are actively involved to carry out problem exploration activities, to turn contextual problems into mathematical problems 
(Sitorus, 2016). The results of student exploration are not only aimed at finding the end of the given problem, but are also directed to develop various problem-solving strategies that can be used (Dickinson et al, 2010).

b. Use models

The use of models serves as a bridge between the concrete and abstract levels. The diversity of models and symbols, and activity designs are intended to bring students' thoughts to knowledge development (Afriansyah, 2016). First, the model may be simple or in the form of informal mathematics (model of), then through generalization or formalization students can develop a more general model that leads to formal mathematics (model for) (Summirattana, 2017).

c. Student contribution

Students' understanding of the first and second RME characteristics, namely phenomenological exploration and using models (Julie, 2014). In learning activities, students are given the opportunity by the teacher to find mathematical concepts in their own way. Students under the guidance of teachers are given the freedom to build their own knowledge in finding mathematical concepts.

d. Interactivity

The student learning process will become more meaningful when students and teachers discuss, give ideas and communicate their work (Fauziah, 2017). The use of interaction in learning mathematics is useful in developing students' cognitive and affective abilities simultaneously.

e. Intertwinment

Realistic Mathematics Education places the relationship between mathematical concepts as things that must be considered in the learning process. In preparing formal mathematics students need to make connections between the knowledge they already have to acquire new knowledge (Julie et al, 2014). Dicknison et al, (2010) added that linking mathematical concepts is the right strategy for solving problems, so students are encouraged to reflect on the knowledge they already have so that they acquire new knowledge.

\section{METHOD}

The method used is the development research method. The development model chosen is the development of learning design that refers to the Instructional Development Model (MPI). The procedure in compiling an instructional system, first to identify, second to develop and thirdly, to evaluate and revise (Suparman, 2014).

The design of learning mathematics that will be developed focuses on the subject of quadrilaterals. The learning design made is adjusted to the instructional objectives because it will be used by students, as a guide for realizing the mathematics learning process so that the objectives and learning outcomes are achieved.This research is limited to junior high school students, namely for class VII according to the needs analysis and student analysis.

\section{RESULTS AND DISCUSSION}

\section{Learner Analysis}

Student analysis, this learning design was developed for Grade VII Junior High School students using the RME approach on quadrilateral material. The application of RME in quadrilateral learning is suitable to be applied to junior high school students. This is in line with what was stated by Piaget (2010) that students at the junior high school level are in the formal operational stage. At this stage students already have the capacity to use abstract principles, so that students are able to learn abstract learning materials such as rectangles.

Reigeluth (1993) describes the characteristics of students in knowledge, one of which is analogic knowledge. This knowledge is new knowledge that links knowledge with students' abilities, as well as new knowledge that is still the same and similar and is outside the topic or content being read. This characteristic of knowledge is appropriate and relevant to the application of the RME Approach in learning, because it is in line with constructivism theory which emphasizes the process of building 
or compiling new knowledge in students' cognitive structures based on experience (Sanjaya, 2006; Bunga et al., 2016). In addition, the learning process in this theory is concrete and closely related to nature and the surrounding environment (Pribadi, 2009). So it can be said that the RME approach is closely related to the theory of constructivism, where in its learning it emphasizes the importance of real contexts that are close to students' daily lives or can be imagined by students (imageable). That way students can understand the quadrilateral by constructing the concrete with the abstract in the learning activities of quadrilateral material in junior high school, because of the connection with the real world (realword).

\section{Needs Analysis}

The quadrilateral material is one of the subjects that must be studied by seventh grade junior high school students in mathematics, because it is in accordance with the provisions of the Ministry of Education (2019) listed in the syllabus (table 1). After studying the quadrilateral, students are expected to have an understanding and ability of what they have learned, so that the quality of mathematics learning is better (Masitoh \& Prabawanto, 2016). Understanding the concept of quadrilaterals in junior high school students is indeed very important, but the reality is not fully optimal. Conditions in the field describe the opposite of what is desired. Students only memorize formulas for flat shapes that already exist and are less able to master the properties of these shapes with the concepts they have (Hakim, 2019). As explained in the previous background that based on the results of previous studies that have been carried out by several researchers, it is known that students still have difficulty understanding quadrilaterals. Even though quadrilateral learning for junior high school students is very important as a prerequisite material in studying other materials, such as building space and similarity (Darmawati, et al., 2020)

TABLE 1. Core Competencies and Basic Competencies

\begin{tabular}{|c|c|}
\hline Core Competencies & Basic competencies \\
\hline $\begin{array}{l}\text { 1. Understanding knowledge (factual, conceptual, and } \\
\text { procedural) based on their curiosity about science, } \\
\text { technology, art, culture related to visible } \\
\text { phenomena and events }\end{array}$ & $\begin{array}{l}\text { 3.11 Associate the perimeter and area } \\
\text { formulas for various types of } \\
\text { quadrilaterals (square, rectangle, } \\
\text { rhombus, parallelogram, trapezoid, and } \\
\text { kite) and triangles. }\end{array}$ \\
\hline $\begin{array}{l}\text { 2. Trying, processing, and presenting in the concrete } \\
\text { realm (using, parsing, assembling, modifying, and } \\
\text { creating) and abstract realms (writing, reading, } \\
\text { counting, drawing, and composing) according to } \\
\text { what is learned in school and other sources in the } \\
\text { same perspective. /theory. }\end{array}$ & $\begin{array}{l}\text { 4.11 Solve contextual problems related to } \\
\text { the area and perimeter of quadrilaterals } \\
\text { (squares, rectangles, rhombuses, } \\
\text { parallelograms, trapezoids, and kites) } \\
\text { and triangles }\end{array}$ \\
\hline
\end{tabular}

The importance of quadrilateral learning, therefore we need a learning model that contains contextual activities, in order to build student constructivity, develop models, and take advantage of existing understanding to make it easier to understand abstract material, so that it can become real (Mahendra et al, 2017). One approach to learning mathematics that is contextually oriented or realistic mathematization is the RME Approach (Martadinata, 2020). The RME approach is one of the learning approaches that has the potential to implement an effective teaching and learning process, especially in quadrilateral learning in junior high schools because it leads to explanations related to realistic things. 


\section{Task Analysis}

The task analysis in this research is to design mathematics learning in the quadrilateral material of seventh grade junior high school students, on the subject of square and rectangular material, by applying the RME characteristics. This learning aims so that students can understand the area and perimeter of the figure, so that they can solve related problem solving. According to Brown \& Green (2011) task analysis aims to assess and overcome the differences between what students know and what they need to learn so as to achieve the expected goals.

a

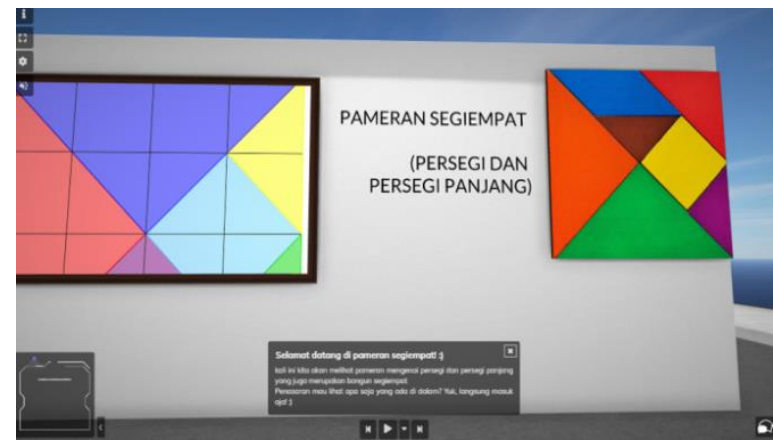

b

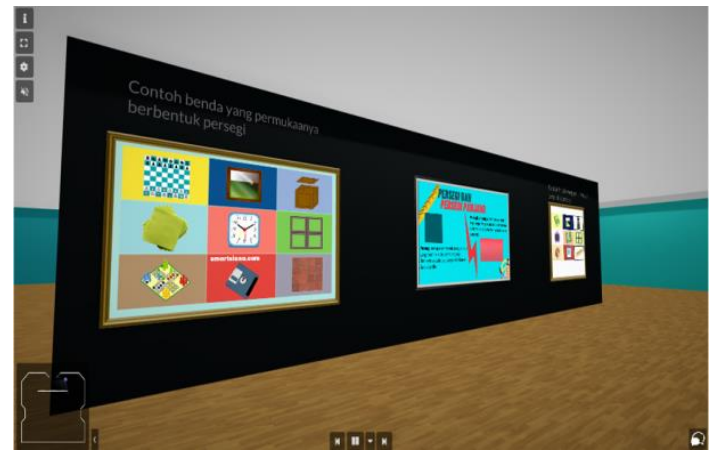

FIGURE 1.(a) Sample Visual Aids for Introducing Square and Rectangle Topics; (b) Example Exercises: Students are Asked to Name Examples of Shapes.

The outline of the planned activities by applying the RME characteristics to design learning on quadrilateral material with the subject of square and rectangle for class VII is shown below:

TABLE 2. Quadrilateral Learning Design by Applying RME

\section{Learning Activities Quadrilateral (Square and Rectangle)}

1) Prerequisite knowledge. Before discussing squares and rectangles, students must be proficient in the prerequisite materials, so ask/review the following materials:
a. Algebra
b. Number operations
c. Powers and roots
d. Elements of a quadrilateral
e. All kinds of rectangles

2) Observing objects around (such as table, book, wall clock)

3) Observing the quadrilateral

4) Mention the various types of quadrilaterals

5) Introducing square and rectangular shapes and their properties

6) Generalize the observation of the context of flat shapes so that an understanding of the circumference and area is obtained.

7) Determine the area and perimeter of squares and rectangles and evaluate them by discussion.

8) Shows available learning resources for the topic. In this study using VR media and worksheets that are in accordance with realistic mathematics as visual aids.

9) Distribute student activity sheets to groups that are used to apply concepts, use realistic problems, and make decisions that require many answers and/or many ways to solve problems.

10) Provide questions or feedback from students to other students regarding

\section{RME}

Characteristics

Intertwinment

Use of context

Use of model

student

contribution 
other students' presentations.

interactivity

11) Summarize what was learned during the lesson.

12) Reflect on the activities that have been learned.

13) Giving homework with different questions, this is done to determine the level of student ability in the material that has been studied.

14) Deliver the topic assessor for the next day's lesson

\section{Performance Objectives and Learning Outcomes}

Learning outcomes and objectives are the keywords used by instructional design to describe changes in knowledge, behavior, performance achieved through an instructional activity. Brown and Green (2011) show that the result is a skill that is achieved through an instruction, while the goal is a measurable action that aims to achieve broader results. Learning objectives are also referred to as performance goals, because several types of performance or competency standards are sought to be achieved.

\section{Lesson Objectives}

The following describes the learning objectives developed in discussing square and rectangular material. Students can demonstrate and apply this knowledge using several measures, namely:

1) Students are able to name the properties of rectangles and squares.

2) Students are able to find the formula for the perimeter of a rectangle and a square.

3) Students will be able to find the formula for the area of a rectangle and a square

4) Students are able to solve problems related to the perimeter of rectangles and squares

5) Students are able to solve problems related to the area of a rectangle and a square

\section{Appropriateness of Selected Lesson Objectives}

The subject of squares and rectangles in quadrilateral material is an important concept that leads to further generalizations in geometry learning. Therefore, students need to have an understanding of the properties, perimeter and area of squares and rectangles. Furthermore, after studying and understanding the material, it is hoped that students can apply it in solving related problem solving. The objectives are used to measure whether or how well the material has been understood by students. The objectives developed are suitable for this lesson because they allow some observations of how this material is explained and applied in problem solving by students, as well as evaluating based on students' level of understanding.

The application of RME is in accordance with the learning objectives of the quadrilateral, namely by constructing students' understanding, which is expected to obtain the results to be achieved. This can be seen from the relationship between the characteristics of RME and learning activities. The teaching and learning stage which refers to a realistic mathematical approach, namely the teacher presents the context (use of context), a problem situation that is known and understood by students, then students will make connections (intervewnet) and are expected to be motivated to create a representation of the form of a model (use of model). leads to formal mathematics. These activities are carried out by discussion (interactivity) so that there is a student contribution to build students' knowledge in finding mathematical concepts. This is in line with the opinion of Fasha and Hidayat (2021) that RME approach in learning mathematics can bring students to concrete things.

\section{Learning Outcomes for Each Objective}

After attending the lesson, students are expected to be able to:

1) State the properties of rectangles and squares 
2) Find the formula for the perimeter of a rectangle and a square

3) Find the formula for the area of a rectangle and a square

4) Solve problems related to the perimeter of rectangles and squares

5) Solve problems involving the area of rectangles and squares.

\section{How Learning Outcomes Support Each Objective}

The following is an explanation of the relationship between learning outcomes and objectives, based on learning activities by applying the RME characteristics shown below:

1) Students will be able to name the properties of rectangles and squares

First, presenting information by showing examples of objects whose surfaces are square and rectangular on a projector screen with VR media (figure 1b). The teacher explores students' understanding of the properties of the two shapes through observation and questioning activities. At this stage, the characteristics of the RME that are applied are Intertwinment or linking knowledge and also interactvity, namely questions and answers between teachers and students. So that students can mention the properties of rectangles and squares.

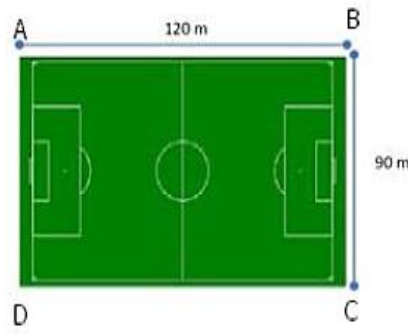

(a)

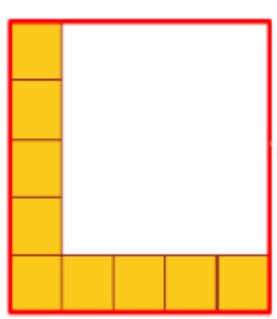

The floor will be covered with square tiles. How many unit squares can cover the floor of the bedroom if a tile is a unit square?

(b)

FIGURE 2. (a) Example of Use Of Model to Determine the Perimeter of a Rectangle; (b) Example of Student Activities to Determine Area

2) Find the formula for the perimeter of a rectangle and a square

The next activity constructs students' understanding by providing contextual problems, namely showing a picture of a football field as shown in Figure 2. The teacher asks students how to determine the circumference of the field. At this stage there is also a question and answer interaction between the teacher and the students until the formula for determining the perimeter of a rectangle is obtained. Understanding the concept of circumference with contextual problems makes it easier for students to construct their knowledge, changing the model of into a for model or formal mathematics into informal mathematics. the use of models in solving mathematical problems. The model as a representation of a problem that is needed to facilitate the completion of the problem works as a "bridge" to vertical mathematization activities (Rahmawati, 2013).

Furthermore, to determine the perimeter of a square, a contextual problem is used which is presented in the student activity sheet as in the following example:

Hannah has a square-shaped handkerchief. The handkerchief is decorated with lace at the edges. If the sides of the handkerchief are $p$ meters, what length of lace must Hana buy to decorate the handkerchief?

Previously in the preliminary activity students already had prerequisite knowledge about the properties of squares. Armed with this knowledge, students can determine the formula for the perimeter of a square by discussing with other students through the given problem (student contribution). 
3) Find the formula for the area of a rectangle and a square

The second activity aims to find the broad concept by coming up with a reallotment strategy to calculate the area of the shape. The teacher begins the lesson by explaining the tiling context contained in the student activity sheet as shown in Figure $2 b$. The context of determining the number of tiles brings students closer to the concept of area where area is the number of units of area (square units) needed to tightly cover a flat shape. Determination of tiles based on area comparison shows the characteristics of the relationship (interviewment) in the RME. There are several assumptions about the student learning process, such as: (1) Students imagine the number of unit squares formed by combining parts that are not tightly closed, and (2) students cut out the part of the shape and shape it into a unit square and then count the number of unit squares.

Based on the activities carried out using realistic contexts assisted by VR and LKS media, it supports the formation of student understanding so that they can determine the perimeter and area of squares and rectangles. In line with that, previous research by Ulandari et al, (2017) this can happen because the materials and problems in the LKS are developed according to the characteristics and environment of the students, so that learning becomes more meaningful in accordance with the objectives of the RME. In addition, RME does not have to be a real-world problem but can be in the form of the use of teaching aids, or other situations as long as it is meaningful and can be imagined in the minds of students (Ubaidilah et al, 2017).

4) Solve problems related to the perimeter and area of rectangles and squares

After students understand the concept of perimeter and area of squares and rectangles by finding the formula. Furthermore, students are expected to be able to apply their knowledge in related problems. Some of the worksheets/questions that can be used include the following questions which can be seen in the evaluating the learning sub-heading.

\section{Learning Events of Instruction and Evaluating The Learning}

The right plan in developing learning, or curriculum in general, namely by detailing the teaching process as well as the process for assessing teaching outcomes (Roubides, 2015), both are important things that must be developed. Furthermore, the learning design developed in this article is intended for Grade VII Junior High School students on quadrilateral material, on square and rectangular subtopics. This article applies the current approach to teaching, namely Gagné's nine events which are used as general guidelines and adapted to the pedagogical model. A slight modification of these instructional events is presented in this article, as well as a discussion of learning assessment after instruction explanation.

\section{Events of Instruction}

Brown and Green (2011) explain the importance of sequencing instructional events in order to create effective teaching as proposed by Gagné (Gagné's nine events). Gagne's proposed instruction framework offers a well-organized and sequential set of procedures and supports the possibility of good processes in instruction. So that learning activities are successful and effective, as stated by Good and Brophy (1990). Here are nine steps of Gagné's instruction that the authors have modified to better suit a learner-centered approach that also supports a cognitive constructivist approach to learning and teaching. An adaptation of Gagné's original nine-step instruction is described below:

1) Get students' attention at the beginning of the lesson, ensure students are ready to learn and motivate them to be involved throughout the learning process.

2) Inform learning objectives and involve them in thinking how they can achieve these learning goals and why they are needed by students.

3) Exploring prior knowledge/ remember lessons. In the following ways: (a) Get students to relate new information to previously learned knowledge; (b) Ask questions about previous 
experiences or learning concepts/content; (c) Provide opportunities for learners to summarize their prerequisite knowledge \& skills.

4) Discuss the subject matter; information presented and discussed

5) Facilitate student learning by enabling self-discovery and improvement of students' metacognitive skills, indispensable for effective transfer of learning from the classroom to the outside world.

6) Provide opportunities to practice the concepts and skills learned to ensure that adequate learning is carried out.

7) Provide appropriate, precise, and constructive feedback specifically.

8) Assess student performance; this is usually a requirement and can be done in a variety of ways, such as group or individual exams or portfolio assessments.

Improving reinforcement (retention) and transfer of knowledge (transfer) is the ultimate goal of instructional activities, that is, concepts and skills learned can be applied to similar situations outside the classroom.

\section{Evaluating The Learning}

Formative and summative assessments are instruments used in evaluating instruction. Each step of Gagné's modified nine-step instruction can provide opportunities for formative assessment (Roubides, 2015). Such assessments can be formal or informal and can be very important in addressing the needs of learners and guiding them. Summative assessment is used to measure students' abilities, such as holding quizzes about certain lesson objectives, and to see whether these goals have been achieved by students.

The following is an example of a quiz/question to assess understanding of the square and rectangle material and its relationship to the objectives and learning outcomes shown below:

1) State the properties of rectangles and squares

The following statements are properties of a square, except

A. Has 4 axes of symmetry

B. Each angle is a right angle

C. The opposite sides are the same length

D. Has two diagonals of the same length, intersecting not to form a right angle.

2) Solve problems related to the perimeter of rectangles and squares

a) A rectangular garden has a length $(x+4) m$ and a width $(3 x+2) m$. If the perimeter of the garden is $60 \mathrm{~m}$, what is the width of the garden?

b) Andi owns a piece of land measuring $20 \mathrm{~m} \times 30 \mathrm{~m}$ (figure $3 \mathrm{~b}$ ), which will be made a garden with a width of $5 \mathrm{~m}$ as shown by the shading area in the picture below. The circumference of Mr. Andi's garden is....

3) Solve problems involving the area of rectangles and squares

a) A square floor has a side length of $6 \mathrm{~m}$. The floor will be installed with square tiles measuring $30 \mathrm{~cm} \times 30 \mathrm{~cm}$. Determine the number of tiles needed to cover the floor

b) Look at the pictures of rectangles $A B C D$ and squares PQRS (figure $3 a$ )! The area of the unshaded area is $529 \mathrm{~cm} 2$. The area of the shaded area is
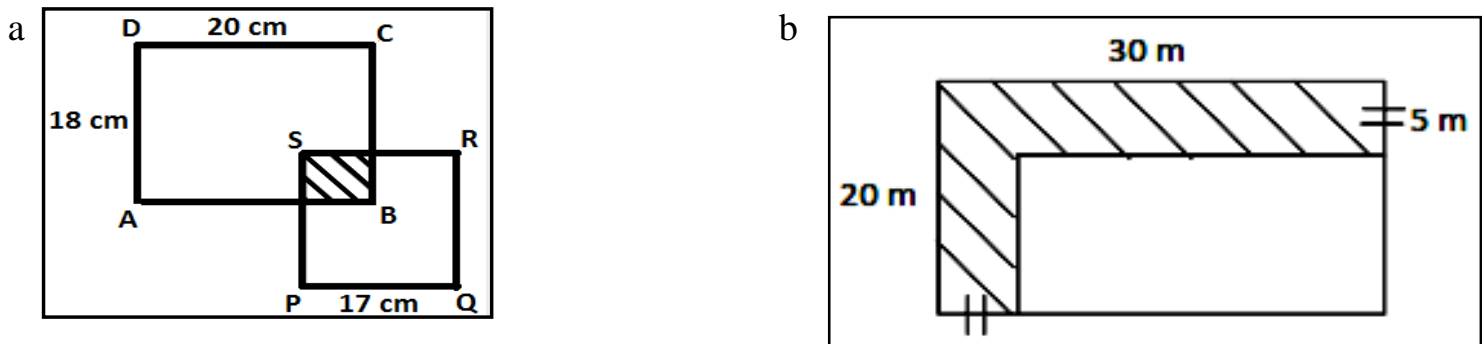

FIGURE 3. (a) Examples of Problems Related to Area; (b) Examples of Problems Related to Circumference 
Scoring of student answers can be assessed using scoring guidelines referring to the modified assessment rubric from Sumaryanta (2015) as follows.

TABLE 3. Quadrilateral Problem Scoring Guidelines

\begin{tabular}{llll}
\hline \multicolumn{1}{c}{ Criteria } & \multicolumn{1}{c}{$\mathbf{0}$} & \multicolumn{1}{c}{$\mathbf{1}$} & \multicolumn{1}{c}{$\mathbf{2}$} \\
\hline $\begin{array}{l}\text { Understanding the } \\
\text { problem }\end{array}$ & $\begin{array}{l}\text { Don't understand the } \\
\text { problem }\end{array}$ & $\begin{array}{l}\text { Don't understand the } \\
\text { problem }\end{array}$ & $\begin{array}{l}\text { Able to understand the } \\
\text { problem }\end{array}$ \\
\hline $\begin{array}{l}\text { Formulate problem } \\
\text { solving }\end{array}$ & $\begin{array}{l}\text { Unable to formulate a } \\
\text { solution }\end{array}$ & $\begin{array}{l}\text { Able to formulate } \\
\text { solutions, but not exact }\end{array}$ & $\begin{array}{l}\text { Able to formulate } \\
\text { solutions appropriately }\end{array}$ \\
\hline $\begin{array}{l}\text { Carry out } \\
\text { troubleshooting }\end{array}$ & $\begin{array}{l}\text { Unable to carry out } \\
\text { problem solving }\end{array}$ & $\begin{array}{l}\text { Able to carry out } \\
\text { problem solving, but } \\
\text { not right }\end{array}$ & $\begin{array}{l}\text { Able to carry out } \\
\text { problem solving }\end{array}$ \\
\hline Making conclusions & $\begin{array}{l}\text { Unable to draw } \\
\text { conclusions }\end{array}$ & $\begin{array}{l}\text { Able to draw } \\
\text { conclusions, but not } \\
\text { right }\end{array}$ & $\begin{array}{l}\text { Able to draw } \\
\text { conclusions }\end{array}$ \\
\hline
\end{tabular}

\section{Formative Evaluation}

Formative evaluation is a process of collecting data and information in order to improve teaching effectiveness. Formative assessment is carried out as a constructive process without containing a decision. However, at a certain point, it is necessary to know whether the teaching has been effective. In order to reach that decision, a summative assessment needs to be carried out. With formative evaluation, teachers can see how far their students have mastered the teaching materials that have been taught (Aji, 2016).

\section{Summative Evaluation}

Summative evaluation is the process of collecting data and information in order to make decisions about the acquisition of learning objectives that have been designed. Through summative evaluation, a learning design that has a basis for assessment decisions based on effectiveness and efficiency in teaching and learning activities can be determined and given a value (Aji, 2016). Summative evaluation is directed at the success of achieving the goals that have been set at the beginning shown by student performance. If all the objectives have been achieved, the effectiveness of the implementation of certain subject learning activities is considered successful. Likewise, if student success is achieved in a relatively short span of time, in terms of learning efficiency, it can be achieved. Final, if with this learning design it is possible to apply a good strategy, student learning activities increase, then in terms of success in teaching attractiveness can be achieved.

The Dick and Carey model is an instructional design model, developed by Walter Dick, Lou Carey and James O Carey. Dick \& Carey's research and development model is one of the procedural models, namely a model that suggests that the application of design principles/instructional design is adjusted to the steps that must be followed sequentially. This model consists of 10 steps. The ten steps in the Dick and Carey model show a very clear and uninterrupted relationship between one step and another. In other words, the system contained in Dick and Carey is very concise, but the content is solid and clear from one sequence to the next. This model is included in the procedural model. Learning Design steps according to Dick and Carey (1990) are:

1) Identify general learning objectives

2) Carry out learning analysis

3) Identifying input behavior and student characteristics

4) Formulate performance goals

5) Develop benchmark reference test items

6) Developing learning strategies

7) Develop and select learning materials 
8) Design and carry out formative evaluation

9) Revise learning materials

10) Design and carry out summative evaluations.

The results at the stage above are used as the basis for writing the required tools. The results of the device are then validated and tested in class/implemented in class with summative evaluation. The use of the Dick and Carey model in the development of a subject is intended so that (1) at the beginning of the learning process students or students can know and be able to do things related to the material at the end of learning, (2) there is a link between each component, especially learning strategies and the desired learning outcomes, (3) explain the steps that need to be taken in planning the learning design (Aji, 2016).

\section{CONCLUSION}

In this article there is a research question "how is the design of mathematics learning on the subject of rectangles and squares at the junior high school level by applying RME?" Through the preliminary, analysis, development and evaluation stages, it is known that quadrilateral learning is very important to be taught to junior high school students. Not only learning, but also there are goals to be achieved so as to obtain the expected results or a mathematical ability that students must have.

The importance of quadrilateral learning is one approach that recommends achieving this ability by applying RME. The characteristics of RME have a role in developing the mathematical understanding of class VII students in learning activities on the area and perimeter of squares and rectangles. The following are the conclusions of the results of the development of rectangular learning designs: the use of contexts or realistic problems as a starting point for learning mathematics. In the first activity, the context compares the surrounding objects to determine the properties of the shapes. The context in the second activity finds the concept of circumference with the realworld application. The third activity uses the context of changing the shape of the tiles using formal units,

The context used with visuals on student sheets and VR media in each activity helps develop a model (use model) that students use to solve the problems given. Students' mathematical understanding develops in accordance with the use of students' construction results in each RME activity. Interactivity between teachers and students and between students is well established and is shown in group discussions and class discussions in learning activities. The linkage of several concepts in this study attracted attention and became a motivation for students to solve various problems given.

\section{REFERENCES}

Adhitya, Y. (2018). VAK Grade 7 Students' Error in Mathematical Problem Solving About Quadrilateral. International Journal of Research in Applied, Natural and Social Sciences (IJRANSS), 6(5), 157-164.

Afriansyah, E. A. (2016). Makna Realistic dalam RME dan PMRI. Lemma, 2(2), 145174.

Aisyah, P. N., Nurani, N., Akbar, P., Yuliani, A., Siliwangi, I., Jendral, J. T., \& Cimahi, S. (2018). Analisis Hubungan Kemampuan Pemecahan Masalah Matematis dan Self Confidence Siswa SMP. Journal On Education P, 1(1), 58-65.

Aji, W. N. (2016). Model Pembelajaran Dick and Carrey dalam Pembelajaran Bahasa dan Sastra Indonesia. Kajian Linguistik dan Sastra, 1(2), 119-126.

Astuti, N. R. (2019). The Effect of RME on Mathematics Learning Outcomes Viewed Mathematic Communication Skills. International Journal of Educational Research Review, 5(1), 43-53.

Brown, A., Green, T. D. (2011). The essentials of instructional design: Connecting fundamental principles with process and practice. Boston: Allyn \& Bacon.

Bunga, N., \& Julia, J. (2016). Pendekatan Realistic Mathematics Education untuk Meningkatkan Kemampuan Koneksi dan Komunikasi Matematis Siswa. Jurnal Pena Ilmiah, 1(1), 441-450. 
Darmawati, D., Irawan, E. B., \& Chandra, T. D. (2017, June). Kesalahan siswa SMP dalam menyelesaikan soal bangun datar segiempat berdasarkan teori Nolting. In Prosiding Seminar Nasional Mahasiswa Kerjasama Direktorat Jenderal Guru dan Tenaga Kependidikan Kemendikbud 2016.

Dick, W. and Carey, L. (1990). The Systematic Design of Instruction. (Third ed.). United States of America : Harper Collins Publishers.

Dickinson, P., Eade, F., Gough, S., \& Hough, S. (2010). Using Realistic Mathematics Education With Low to Middle Attaining Pupils In Secondary Schools. In Proceedings of the British Congress for Mathematics Education (Vol. 5, No. 1, pp. 34-46).

Fauzan, Ahmad dan Diana, Fitri. (2018). Pengembangan Desain Pembelajaran Topik Pola Bilangan Berbasis Realistic Mathematics Education (RME) di Kelas VIII SMP/MTS. I Jurnal Edukasi dan Penelitian Matematika), 7(4), 43-52.

Fauziah, A., \& Putri, R. I. I. (2017, December). Primary School Student Teachers' Perception to Pendidikan Matematika Realistik Indonesia (PMRI) instruction. In Journal of Physics: Conference Series (Vol. 943, No. 1, p. 012044). IOP Publishing

Good, T., Brophy, J.(1990). Educational Psychology: A realistic approach. New York: Holt, Rinehart, \& Winston.

Gravemeijer, K. (1994). Developing realistic mathematics education. Utrecht: CD- $\beta$ Press.

Gravemeijer, K. (2010). Realistic Mathematics Education Theory as A Guideline for ProblemCentered, Interactive Mathematics Education. In R. Sembiring, K Hoogland \& M. Dolk (Eds.), A decade of PMRI in Indonesia, (pp.41-50). Bandung, Utrecht: APS International

Günhan, B. C. (2014). An Investigation of Pre-Service Elementary School Teachers' Knowledge Concerning Quadrilaterals. Çukurova University. Faculty of Education Journal, 43(2), 137.

Hadiyanti, Y. R. (2016). Deskripsi Kesalahan Siswa dalam Menyelesaikan Soal - Soal Penerapan Bangun Datar Segi Empat di Kelas VII D Semester 2 SMP YPK Kotaraja. Jurnal Ilmiah Matematika Dan Pembelajarannya, 2(1), 10-17.

Hakim, I. D., \& Ramlah, R. (2020). Analisis Kemampuan Pemahaman Konsep Materi Segitiga dan Segiempat pada Siswa SMP. Prosiding Sesiomadika, 2(1d).

Hamzah dan Muhlisrarini. 2014. Perencanaan Dan Strategi Pembelajaran Matematika. Jakarta: PT Raja Grafindo Persada.

Hidayat, Y. R., \& Fasha, L. H. (2021). Hasil Belajar Peserta Didik Dalam Pembelajaran Matematika Realistik di Kelas IV SD Negeri 195 Isola Kota Bandung. COLLASE (Creative of Learning Students Elementary Education), 4(4), 640-65

Inharjanto, A., \& Lisnani, L. (2019, April). Implementing Realistic Mathematics Education for Elementary Schools in Indonesia. In International Conference on Educational Sciences and Teacher Profession (ICETeP 2018) (pp. 188-191). Atlantis Press

Jamaan, E. (2018). Pengembangan Disain Pembelajaran Materi Bangun Ruang Berbasis Realistic Mathematics Education untuk Meningkatkan Kemampuan Berpikir Kritis Matematis Siswa.

Julie, H., Suwarsono, S., \& Juniati, D. (2014). Understanding Profile from the Philosophy, Principles, and Characteristics of RME. Indonesian Mathematical Society Journal on Mathematics Education, 5(2), 148-159.

Laurens, T., Batlolona, F. A., Batlolona, J. R., \& Leasa, M. (2017). How Does Realistic Mathematics Education (RME) Improve Students' Mathematics Cognitive Achievement?. Eurasia Journal of Mathematics, Science and Technology Education, 14(2), 569-578.

Mahendra, R., \& Slamet, I. (2017, September). Problem Posing with Realistic Mathematics Education Approach in Geometry Learning. In Journal of Physics: Conference Series (Vol. 895, No. 1, p. 012046). IOP Publishing.

Martadinata, I., \& Araiku, J. (2020, March). Design of Mathematics Learning in The Grand Mosque of Palembang. In Journal of Physics: Conference Series (Vol. 1480, No. 1, p. 012005). IOP Publishing.

Masitoh, I., \& Prabawanto, S. (2016). Peningkatan Pemahaman Konsep Matematika dan Kemampuan Berfikir Kritis Matematis Siswa Kelas V Sekolah Dasar Melalui Pembelajaran Eksloratif. EduHumaniora| Jurnal Pendidikan Dasar Kampus Cibiru, 7(2), 186-197. 
Nisiyatussani, N., Fathurrohman, M., \& Anriani, N. (2018). Geogebra Applets Design and Development For Junior High School Students to Learn Quadrilateral Mathematics Concepts. Journal on Mathematics Education, 9(1), 27-40.

Panhuizen, Marja van den Heuvel dan Paul Drijvers. 2014. "Realistic Mathematics Education". Jurnal. Encyclopedia of Mathematics Education, Dordrecht, Heidelberg, New York, London: Springer. Freudenthal Institute for Science and Mathematics Education Utrecht University.

Permendikbud No 24. Lampiran 15. KI dan KD, K-13 SMP-MTs Matematika 2016, Tersedia :http://drive.google.com/file/d/1WMTBSAqvf0i4WgfVCokXjtdtni5H3Tf3/view, (Minggu, 3 Maret 2019)

Piaget, Jean \& Barbel Inhelder. (2010). Psikologi Anak. (penerjemah: Miftahul Jannah). Yogyakarta: Pustaka Belajar.

Pribadi, B. A., \& Sjarif, E. (2010). Pendekatan konstruktivistik dan pengembangan bahan ajar pada Sistem Pendidikan Jarak Jauh. Jurnal pendidikan terbuka dan jarak jauh, 11(2), 117-128.

Rahaju, E. B. (2018). The Thinking Process Of Field Independent Cognitive Style of Junior High School Student in Defining Quadrilateral Concept. In Journal of Physics: Conference Series (Vol. 953, No. 1, p. 012207). IOP Publishing.

Rahmawati, F. (2013). Pengaruh Pendekatan Pendidikan Realistik Matematika dalam Meningkatkan Kemampuan Komunikasi Matematis Siswa Sekolah Dasar. Prosiding SEMIRATA 2013, 1(1).

Reigeluth, C. M. (n.d.).(1993). Instructional Theory and Technology for the New Paradigm of Education.

Roubides, P. (2015). An Instructional Design Process for Undergraduate Mathematics Curriculum Online. Procedia Computer Science, 65, 294-303.

Rudiono, T., Dafik, D., \& Wahyuningrum, E. (2015). Pengembangan Perangkat Pembelajaran Berbasis RME Berorientasi Terciptanya Berfikir Tingkat Tinggi Materi Perbandingan Kelas VII. Pancaran Pendidikan, 4(1), 45-54.

Sanjaya, Wina. 2009. Startegi Pembelajaran: Berorientasi Standar Proses Pendidikan. Jakarta: Kencana.

Sitorus, J. (2016). Students' Creative Thinking Process Stages: Implementation of Realistic Mathematics Education. Thinking Skills and Creativity, 22, 111-120.

Sumaryanta. (2015). Pedoman Penskoran. Indonesian Digital Journal of Mathematics and Education,Vol. 2 No. 3 Tahun 2015.

Sumiati, A., \& Agustini, Y. (2020). Analisis Kesulitan Menyelesaikan Soal Segiempat dan Segitiga Siswa SMP Kelas VIII di Cianjur. Jurnal Cendekia: Jurnal Pendidikan Matematika, 4(1), 321 331.

Sumirattana, S., Makanong, A., \& Thipkong, S. (2017). Using Realistic Mathematics Education and the DAPIC problem-solving process to enhance secondary school students' mathematical literacy. Kasetsart Journal of Social Sciences, 38(3), 307-315.

Suparman, Atwi. 2014. Desain Instruksional Modern Panduan ParaPengajar \& Inovator Pendidikan. Jakarta: Erlangga

Treffers, A. (1987). Three Dimensions. A Model of Goal And Theory Description In Mathematics Education. Dordrecht, the Netherlands: Reidel.

Ubaidillah, M. F., Subanji, S., \& Sa'dijah, C. (2017, June). Bahan Ajar Berbasis Realistic Mathematic Education (RME) Materi Operasi Hitung untuk Siswa Sekolah Dasar. In Prosiding Seminar Nasional Mahasiswa Kerjasama Direktorat Jenderal Guru dan Tenaga Kependidikan Kemendikbud 2016.

Ulandari, L., Amry, Z., \& Saragih, S. (2019). Development of Learning Materials Based on Realistic Mathematics Education Approach to Improve Students' Mathematical Problem Solving Ability and Self-Efficacy. International Electronic Journal of Mathematics Education, 14(2), 375-383.

Van den Heuvel-Panhuizen, M., \& Drijvers, P. (2020). Realistic Mathematics Education. Encyclopedia of mathematics education, 713-717.

Wijaya, Ariyadi. (2012). Pendidikan Matematika Realistik: Suatu Alternatif Pendekatan Pembelajaran Matematika. Yogyakarta: Graha Ilmu. 